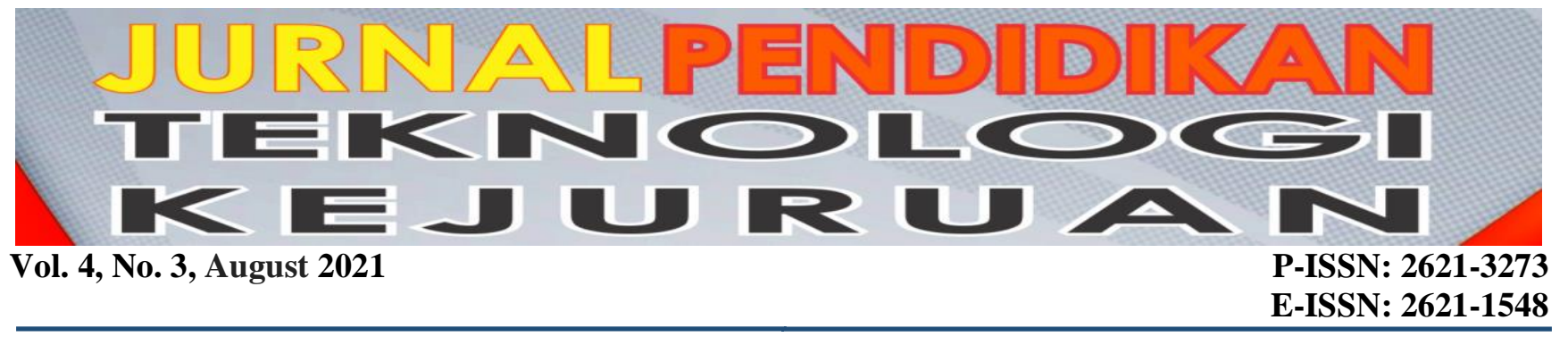

\title{
Implementation of E-Learning Using The Moodle (Study Of Case : STAI Tuanku Tambusai) STMIK Hang Tuah Pekanbaru
}

\author{
Rika Melyanti $^{1^{*}}$, Anita Febriani ${ }^{2}$ \\ ${ }^{1}$ Information System, STMIK Hang Tuah Pekanbaru, ${ }^{2}$ STMIK Hang Tuah Pekanbaru \\ *Corresponding author, e-mail: camelya2105@gmail.com
}

\begin{abstract}
STAI Tuanku Tambusai Pasir Pangaraian is a high school for Islamic religious education, which in the Teaching and Learning Process (PBM) is currently trying to apply the concept of blended learning by using e-learning. The purpose of this research is to build a Learning Management System (LMS) that can assist lecturers and students in conducting PBM with the help of computer technology. This is felt to have become a necessity during the pandemic and industrial revolution 4.0, STAI should have an e-larning that is able to answer challenges. The online learning system service architecture (e-learning) can be used as an appropriate design in the development of learning methods where the level of flexibility, scalability and functionality can make PBM easier to do anywhere and anytime. The designed online learning system (e-learning) at STAI Tuanku Tambusai is used by two actors, namely students and lecturers.
\end{abstract}

Keyword: LMS, blended learning, online learning, e learning, online

\section{INTRODUCTION}

The development of information and communication technology (ICT) in this era of globalization seems irresistible in terms of human life in the 21st century. The speed of this ICT movement can be clearly observed in the fields of business, economy and also government with the emergence of concepts and applications in the form of egoverment, e-commerce, e-community and so on. This phenomenon has become a trend and is gradually shifting conventional methods. Likewise in the world of education, along with the rapid development of information and communication technology, currently the terms Elearning, online learning, web based training, online courses, web based education and so on have emerged, and there are also many educational institutions that use the system. E-learning to increase the effectiveness and flexibility of learning.

The birth and development of E-learning in the world of learning is expected to increase the effectiveness and efficiency in the teaching and learning process. Especially in providing learning media that is able to facilitate lecturers as educators with the use of ICT, namely being able to provide lecture material, assign assignments to students, create discussion forums that can be seen by all participants and lecturers and can easily provide lecturers with space to manage classes and document assignments. as well as a systematic and well documented assignment assessment. According to (Irawan et al., 2015) The use of information and communication technology in the teaching and learning process must be carried out properly and directed in order to be able to provide good quality learning. So that there needs to be a joint increase in learning methods, communication and interaction between students and teachers that facilitate sharing activities (sharing) learning resources and discussion activities without being hindered by time and space.

Of the many e-learning platforms that have begun to expand, there is one that is quite reliable and is the best choice, namely Moodle. By using E-Learning, this learning model becomes more flexible and fun. 5 This is different if learning uses books only. This elearning platform is widely used in schools, because it gives a positive response to both students and teachers. This means that by wearing it, students are more enthusiastic in learning. Meanwhile, teachers find it easier to compile teaching material. 
From the opinion of several experts, it is concluded that e-learning is an innovative approach in distributing the learning process whose model is student-centered, can be more interactive and learning for everyone that can be done at any time to access material and assignments using attributes and sources of various digital and e-learning technology media are more flexible (Santi Maudiarti, 2018). Meanwhile in the research conducted by (Popovici \& Mironov, 2015) it was found that almost all students (98.11\%) considered that they had moderate and advanced skills in using computers or laptops, while 96.52\% of students stated their level of expertise. the same for Internet use (search engine, email). In fact, in all categories of hardware components (iPads and Smartphones) more than 50\% of students stated moderate or higher level of competence while for all categories of applications and services the rates exceeded $67 \%$ (text editor $-84.78 \%$, data processing - $89,56 \%$, mobile apps $-66.96 \%$, socialization and communication space - $90.43 \%$, study rooms $82.61 \%$. It is also important to underline that more than $62 \%$ of students spend at least 5-6 hours per day using technology, with $8 \%$ citing more than 10 hours. Correspondingly, $67.83 \%$ of students contributed by commenting on online articles, while $42.61 \%$ of them had blogs or personal websites. With the advent of the Internet and new technologies, e-learning has become a promising solution for the University which is currently in an environment of intense change.Take into account students' perceptions of e-learning technology, and recognize that student expertise in this area is essential to successful development. Think of the academic program, because the attitude of the end user towards the application of information technology is one of the most effective factors.

This research was carried out based on the initial study of researchers who found problems related to the e-learning system at STAI Tuanku Tambusai Pasir Pangaraian, namely the absence of an LMS (Learning management System) based learning model with the development of Moodle Software (Modular Object Oriented Dynamic Learning Environment). 6 The existing learning system, we have hit Covid 19 as a pandemic, STAI only relies on social media such as WhatApps and email to send and receive assignments and lecture materials, and use zoom and google meet for face-to-face if needed. Course assignments and materials have not been stored and documented properly, so the study program cannot track and know for sure whether the learning process continues or not.

Of the several problems in the current learning process at STAI Tuanku Tambusai Pasir Pangaraian as mentioned above, it is necessary to conduct special research related to LMS-based Learning Model (Learning Management System) with Moodle Software Development (Modular Object-Oriented Dynamic Learning Environment ).

\section{Research Contribution}

The main output of this research is in the form of making and implementing e-learning using Moodle, which will be used by the study program at STAI TuankuTambusai in a learning process that uses ICT and is very effective as a medium for distance learning and effective during the Covid 19 period.

\section{METHOD}

\section{A. Research Approach}

This study uses a Research and Development approach (research and development). Research and development methods are research methods used to produce certain products and test the effectiveness of these products (Sugiyono, 2007: 297). The Research and Development Model is as follows:

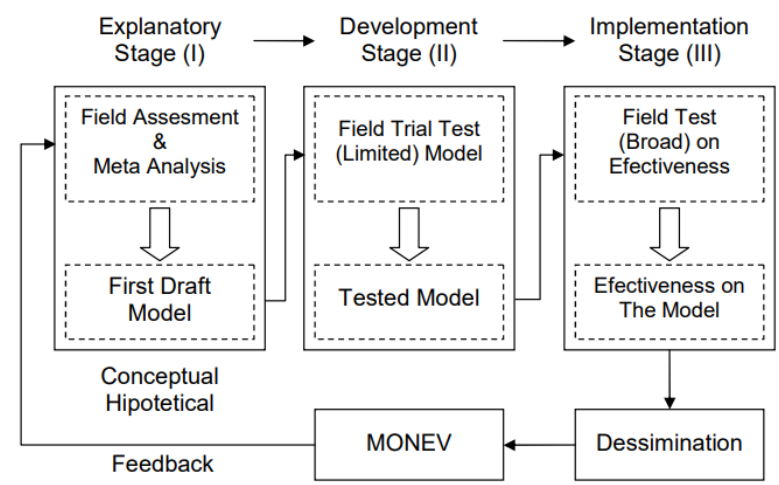

Figure 1. Model Research and Development

\section{B. Data Collection Methods}

\section{Field Research}

a. Interview

The interview is a data collection method that is carried out by conducting questions and answers with Hidayati, S.Kom, M.Ag as the Chairperson of STAI Tuanku Tambusai Pasir Pangaraian along with IT staff and several lecturers from the 2 (two) study programs.

b. Observation

Direct observation or observation is the collection of data by conducting direct research on the environmental conditions of the object of research that support research activities, so that a clear picture of the condition of the object of research is obtained. 
Library Research

This research is intended to obtain an adequate theoretical basis in compiling this research by studying literature theories, books related to research assignments and searching for data on the internet..

C. Place and Time of Research

The place for the implementation of this research is STAI Tuanku Tambusai which is addressed in Riau No. 02 Pasir Pengaraian, Rokan Hulu Riau Regency. And the time used by researchers for this research was carried out from November 2020 to May 2021.

\section{RESULTS AND OUTCOMES ACHIEVED}

1. The Moodle software model that suits the needs of STAI Tuanku Tambusai Pasir Pengaraian.

Based on the identification results of hardware conditions, software, and human resources in the field of information technology STAI Tuanku Tambusai Pasir Pangaraian, e-learning can be developed with Moodle software. Therefore, the next step is to develop Moodle software to support e-learning in accordance with the expectations and needs of the campus. Moodle software development is carried out by making modifications according to the campus e-learning needs, by considering several things, namely: appearance, content, and other facilities (a.l. editing and security). The Moodle software modification was carried out by the Research Team by following them following steps:

1. Identifying e-learning needs that will be used at the STAI Tuanku Tambusai Pasir Pangaraian campus.

2. Design and manufacture of e-learning with Moodle software to support e-learning on campus.

3. Testing and validating the software model that has been tailored to the needs of the campus.

4. Revision of the Moodle software based on the results of trials with users (lecturers, IT staff and students).

Based on the identification results of the two STAI Tuanku Tambusai study programs, the Research Team then made adjustments to the Moodle software to make it more familiar and more effective to use. The customizable aspects include: interface, dragmath, font customization, language. In addition, it is necessary to make adjustments in terms of maintenance and management of e-learning (organizing campus personnel to anticipate limited human resources). The results of the Moodle software development were then tested on lecturers, IT staff and students, the test results showed that for the display it was not a problem, what needed important attention was the content that had to be adjusted to the needs of STAI Tuanku Tambusai Pasir Pangaraian.

Based on the results of these trials, the Moodle software was revised and then used for training in the use of e-learning for lecturers and students, campus officers / admins who manage IT at STAI Tuanku Tambusai Pasir Pangaraian.

\section{CONCLUSION}

From the research that has been done by building an LMS using Moodle which will be used as e-learning in the teaching and learning process at STAI Tuanku Tambusai Pasir Pangaraian it can be concluded as follows:

1. E-learning can help lecturers and students in facing lectures and is very helpful for lecturers in providing teaching materials, learning videos and assignments

2. The initial test, namely user authentication has been running well without any constraints, each logged in user can enter elearning according to their status.

3. The function of the STAI Tuanku Tambusai e-learning application which was made with moodle has been running well.

\section{Advice}

From the results of the research and the conclusions that the author has made, there are several suggestions, because the author is very aware that making elearning applications cannot exceed the capabilities of other large campus e-learning applications. The suggestions in this study are as follows:

It is recommended that this application be validated by experts in both education and technology to ensure its function and suitability with the learning model which is expected to be an aid in graduate learning outcomes and course learning outcomes.

\section{REFERENCES}

Gilbert, \& Jones, M. G. (2001). E-Learning is e-normous. Electric Perspectives, 26(3), 66-82.

Irawan, Y., Susanti, N., \& Triyanto, W. A. (2015). ANALISA DAN PERANCANGAN SISTEM PEMBELAJARAN ONLINE (E-LEARNING) PADA SMK MAMBAUL FALAH KUDUS. Simetris : Jurnal Teknik Mesin, Elektro Dan Ilmu Komputer. https://doi.org/10.24176/simet.v6i2.471 
Popovici, A., \& Mironov, C. (2015). Students' Perception on Using e-learning Technologies. Procedia Social and Behavioral Sciences, 180(November 2014), 1514-1519.

https://doi.org/10.1016/j.sbspro.2015.02.300

Santi Maudiarti. (2018). Penerapan E-Learning Di Perguruan Tinggi. PERSPEKTIF Ilmu Pendidikan, 32(1), 53-68.

Soekartawi. (2017). E-learning: Konsep dan Aplikasinya. Paper Presented in Balitbang Depdiknas Seminar, 18 Februari 2017, November, 1-200.

Sohn, B. (2005). E-learning and primary and secondary education in Korea. KERIS Korea Education \& Research Information Service, 2(3), 6-9. 